\title{
Indian Handicrafts and Globalization: A Review
}

\author{
Nidhi Vats \\ Assitt. Professor, Department of Home Science (CT) Kurukshetra University, Kurukshetra, Haryana, India
}

\begin{abstract}
Indian Handicrafts are the integral parts of the Indian culture and tradition which constitutes a significant segment of the decentralized sector of the economy. Foreign fashion industry borrows a great deal from Indian appliquéd motifs Saree designs, an ethnic Indian wear for their fashion shows. Needless to say, the borders between the world cultures are now eroding out and becoming irrelevant. But notwithstanding, the real concern for many of us is that, can the 'local' really meet with the 'global' by truly sustaining its localness? The biggest problem in the Indian Handicraft industry is that the village craftsmen remain concerned with local trade and mass production so their hand-made products of their hard labour will remain out price from other parts of the world. So the basic question arises, is globalization a panacea for every human problems that the mother earth is facing now? With a brief theoretical understanding, this paper looks at globalization's increasing impact on Indian handicrafts and crafts persons. It tries to assess how far globalization serves as an opportunity and threat to the artisans. The role of the government in promoting the crafts and protecting the artists will also be discussed before concluding the paper.
\end{abstract}

Key Words: globalization, handicraft, sustaining

\section{Introduction}

Handicraft is man's first technology, the technology of the hand. A handicraft at its finest represents man's need to create simultaneously with mind and hand. India is one of the important suppliers of handicrafts to the world market. The Indian handicrafts industry is highly labour intensive cottage based industry and decentralized, being spread all over the country in rural and urban areas. Numerous artisans are engaged in crafts work on part-time basis. The industry provides employment to over six million artisans (including those in carpet trade), which include a large number of women and people belonging to the weaker sections of the society. In addition to the high potential for employment, the sector is economically important from the point of low capital investment, high ratio of value addition, and high potential for export and foreign exchange earnings for the country. India, a country with 35 states and UT and 22 languages and more than 1500 dialects offers an enormous range of handicrafts from each of the states. Major centres in Uttar Pradesh are Moradabad also known as the "Peetalnagari" (City of Brass), Saharanpur for its wooden articles, Ferozabad for Glass. The North Western state of Rajasthan has to offer the famous Jaipuri quilts, Bagru and Sanganer printed textiles and wooden and wrought iron furniture from Jodhpur. The coastal state of Gujarat comes with embroidered articles from Kutch. Narsapur in Andhra Pradesh is famous for its Lace and Lace goods. Globalization, which refers to the integration of economic, political, and cultural systems across the globe, has become one of the fashionable buzzwords in both academic and political debate these days. Reduction of poverty and rapid economic growth in countries like India, China, and other countries that were poor few years ago, proposes sufficient promises about globalization. Nowadays, globalization has laid to the end of geography and also the death of distance. Drastic development in the technologies of transport and communication has made available of everything at everybody's doorstep. The Internet have helped this process, enabling business to communicate more smoothly and efficiently and sparking what some have called the "Third Wave" of economic growth. Even in India, in the local supermarket, different products of foreign origin catch the attention of its home consumers. The information flow so fast that many foreign fashion shows are run these days with models wearing the sarees designed by Indian fashion designers. This shows how tradition meets with modernity these days. Globalization has put both east and west into one compartment and makes a single village - a global village.

This paper basically deals with the globalization creates a world homogenous in nature and other that world cultures are becoming more and more diverse leading to heterogeneity in its form and content. It is in between these debates that my argument for Indian handicrafts evolves.

\section{The Integration - Imperialism Dynamics}

The first discourse talks about the question of homogeneity/uniformity, how the world is gradually becoming one and homogeneous, integrated socially, culturally and economically with the free flow of ideas, values, images etc from one part of the world to other and vice versa. The second discourse that I intend to discuss here is related to the worldwide diversification of culture rather than unification, that there is increasing 
number of heterogeneity in world cultures rather than homogeneity. Instead of assimilation of local culture into global ones, there is accommodation of the two, as a result producing a hybrid culture.

So it is in this backdrop that I analyze the case of Indian handicrafts and crafts persons in subsequent sections. Instead there is fragmentation and greater diversity in the cultural sphere bringing heterogeneity and Globalization doesn't bring total homogeneity.

\section{Crafts Globalization}

Indian handicrafts have very ancient origin and of high quality and has a history of rich and diverse cultural tradition and among its diversity, the legacy of India's craft culture always occupies a special place owing to its beauty, dignity, form, style and aesthetics. "To write about Indian Handicrafts is almost like writing about the country itself so vast, complex and colourful, and yet with a simplicity and charm. The versatility of the various materials used in Indian handicrafts items, such as wood, stone, metal, grass, glass, cane and bamboo, textiles, clay, terracotta and ceramics, makes these products truly unique. Emphasizing on the greater value of the arts and crafts, T.M. Abraham wrote: "the world of art and craft is as valuable as the world of science, philosophy or ethics. Like art, crafts reflect the state of human society through the individual. Craft treasures like art's, give us a glimpse into the core and kernel of the collective mind and societies through the mirror of individual mind that created them" . As said above there are numerous varieties of art crafts in India which are made with attractive designs and meticulous craftsmanship.

With the passage of time, Indian society and economy has changed enormously. It opened up its economy and adapted to globalisation in the early nineties. Major changes initiated as a part of the liberalisation and globalisation strategy. Many Indian companies have started becoming respectable players in the International scene. The liberalisation of the domestic economy and the increasing integration of India with the global economy have helped step up the Gross Domestic Product (GDP) growth rates. In the year1991-92 the GDP growth was just $1.3 \%$,but in 2011-12 it was more than $10 \%$. India is now the fastest growing economy just after China. Indian economy experiences the existence of both traditional handicrafts and modern mechanised production. Though the forces of globalization have ample positive effects in the long-run in many sectors of our economy and society. The growing opportunity for handicrafts in global market is observed when the Indian handicrafts export crossed Rs 1220 crores in 1990-91 from merely 10 crores in the mid fifties . Further the Indian Handicraft Export Council has estimated the export of handicraft goods will touch Rs 52600 crore by year 2013 . During the globalization phase, the growth in handicrafts sector amounts to increasing demand for ethnic and culture-specific goods as a result of growth in world tourism . Indian Handicrafts are said to be just another precious stone of its great culture and heritage. Whether it is the intricately decorated metal craft or some marvelous marble inlay work or some superb paintings or spectacular wood works, Indian handicrafts are going places with their ethnic designs and flourishing textures. Although, the importance of craft in contemporary Indian social and economic life is growing day by day, there is no universally accepted definition of the term in India.

'Handicrafts are items made by hand, often with the use of simple tools, and are generally artistic and/or traditional in nature. They include objects of utility and objects of decoration' Many Indian handicrafts have aesthetic richness and decorative values which have become world famous. For example the artisans who made patta chitra and applique work exclusively for the religious functions in the Lord Jagannath temple in Puri, Orissa developed their skill to make these crafts internationally well-known . Add to it, the Madhubani paintings of Bihar, Kalighat paintings of West Bengal and a number of striking metal crafts, stone carvings and wood carvings from Karnataka, Tamil Nadu, Rajasthan and Madhya Pradesh have become popular both in our native as well as international markets .

India handicrafts constitute a significant segment of the decentralized sector of its economy and it provides employment to millions of artisans scattered especially in the weaker sections of society such as SCs, STs and the women, producing goods worth thousands of Crores of Indian Rupees per year. Because increased export of handicrafts products increase in employment and income. The Annual Report of various years of the Ministry of Textiles, Government of India suggests that the employment in this sector in $47.42 \%$ are women of which $37.11 \%$ are coming under the backward communities like Scheduled Castes/Scheduled Tribes. Indian handicrafts sector forms the second largest employment sector only behind agriculture.

The Handicrafts and Handlooms Exports corporations of India Ltd (HHEC), a Government of India undertaking established in 1962 has been involved in promoting Indian handloom. In the age of globalization, where efficiency meets success, Indian handicraft's further prospect lies in diversification of products and markets. In a highly competitive market, Indian handicrafts need to be ahead of the competitors in keeping themselves informed of current market trend and changes in fashion and design of the consumers. 


\section{The Real Challenge}

Pre-independence the British authorities intentionally promoted the machine made foreign products in Indian markets. India had to supply the raw materials like raw cotton and the British factories had to provide the fine clothes. "So the traditional handicrafts of India which were then world famous were systematically destroyed to create a market for British products". Then after independence the Government of India as a matter of policy wanted to revamp the craft tradition of our country and promote the small scale and cottage industries. It is an altogether different issue how much the craft sector got benefited out of the government sponsored schemes. But it is the present liberalized market system where the craft industry faces vulnerabilities. As there has been the evolution of the modern market economy, the artisans have lost their holds over the old patronclient business network and jajmani relationship. Most of the designs are highly artistic and traditional in nature. But these days some of the modern designs are also being experimented with to suit to the tastes and the preferences of the foreign tourists keeping an eye over the market. The process of making Chandua remained largely unchanged for the past few centuries but during the last two three decades these have undergone tremendous changes. The Chandua makers attribute two reasons for such change in the appliqué work; the first reason is the changing taste of the customers and the second is the commercialization of the products. They are of the opinion that 'when the very survival of the appliqué work owes it to the tourists, it is rather the choice of the tourists that has effected a change on the products and its making style. Customers want the products to be cheaper and attractive. Artisans go for more profit, at times ignoring the quality' .

In the globalization times, though with their products going global and increasing demand for it, there is a rise in the handicraft sector economy, still the artisans have become increasingly dependent on middle men and trader entrepreneurs who pay the artisans wages on piece rate bases. The low bargaining power of the artists in a liberalized and comparatively more competitive market has forced the artisans to depend upon the middlemen. The government's initiative to create cooperatives has not become much successful. Craft workers who have little formal education and are rarely organised are subject to many exploitative work conditions. In Orissa various small scale industries have been facing enormous problems and have failed to compete with the Chinese companies who have intruded into the Orissan market with their low cost products. The precarious condition of the artisans and the crafts is again highlighted when globalization has separated the crafts from the actual artisans. Thus the traditional crafts need to be beautiful and cost effective and maintain proper quality in order to find a place in the competitive market.

\section{The Governmental Intervention}

Although India adapted to libaralisation policies in early nineties, the handicrafts sector continued to get state intervention. Handicrafts being a state subject defined in our constitution, the development and promotion of crafts are the responsibility of the respective state governments. The Central government through various developmental schemes plays the role by supplementing their efforts. As the Annual Report suggests, for the holistic growth and development of the handicrafts, the government during different five-year plan has implemented few generic schemes. These can be discussed below.

1. Baba Saheb Ambedkar Hastshilp Vikas Yojana: The basic objective of this scheme is for a sustainable development of handicrafts through the participation of crafts persons. This scheme is implemented through: (i) social Intervention, i.e. mobilizing the artists,(ii) technological intervention; assisting for design and technological up gradation, reviving the languishing crafts etc., (iii) marketing interventions and (iv) financial interventions.

2. Marketing Support and Service Scheme: This scheme is developed to create awareness ofIndian craft products among the people through: (i) organizing marketing events, (ii)providing services in the form of entrepreneurship and (iii) providing financial assistance to state handicrafts corporations and NGOs for opening new Emporia, etc.

3. Design and Technology Upgradation Scheme: The scheme aims to supply modern tools,upgrade artisans' skills, preserve traditional crafts and revive rare crafts through(i) departmental activities (by giving training in Regional Design \& Technical Development Centres etc.) and (ii) outsourcing (to Shilp Gurus or Heritage Masters, ofdesign and technology upgradation).

4. Export Promotion Scheme: It intends to promote export of handicrafts, including handknotted carpets and floor covering from India. The main components of this scheme are(i) product Development, (ii) publicity and marketing and (iii) social and other welfare measures.

5. Research and Development Scheme: The basic objective of this scheme is to create a regular system of obtaining feedback on economic, social, aesthetic and promotional aspects of various craft goods. It also addresses issues related to WTO. Survey or study of specific crafts on which adequate information is not available, looking at the working conditions of the artisans etc are the major thrust areas under this scheme.

6. Training and Extension Scheme: The scheme aims at enhancing the capacity building of staff of DCHandicrafts, artisans, NGOs etc. 
7. Bima Yojana for Handicrafts Artisans: The Yojana provides life insurance protection to the artisans, either male or female in the age group of 18-60 years. It is being implemented in association with the Life Insurance Corporation of India ltd (LIC).

8. Special Handicrafts Training Projects: Under this programme, the office of the DC-Handicrafts takes initiatives to upgrade the skills of existing as well as new craftpersons, enhance employment opportunities in the handicrafts sector, transfer skills Master Artists to new trainees etc.

Apart from the above schemes, the government is also taking special measures for promotion and development of crafts by popularizing the products and encouraging the artists. The biggest problem while implementing the developmental schemes is the lack of proper knowledge on handicraft units and number of artisans.

\section{Concluding Remarks}

As India opens up her doors to the multinationals during the era of economic reform and liberalized market, putting an end to the license raj, it is not only the economies that often meet in the global market sphere, but also the people and cultures, which bring a new dimension to the multi-cultural setting. The magic of globalization is that during the modern times, there is always a cross-cultural interaction of both the 'local' and 'global' and notwithstanding many contradictions, global village is now not just a possibility, but a reality. Needless to say, the borders between the world cultures are now eroding out and becoming irrelevant. The whole world is now interconnected, But despite, the present day globalization is also branded as a drive for profit making and it as replacement of the local culture by the global.

\section{Reference}

[1] Appadurai, A.(1990).Disjuncture and difference in the global cultural economy.In Featherstone, M., ed. Global culture, Nationalism, Globalization and Modernity: A theory,culture and society special issue. Sage, London.

[2] Valaskakis, K.(1999).Globalisation as Theatre.International Social Science Journal.51(2): 153-164.

[3] Oommen, T.K.(2007).Bringing Gandhi back into Independent India.Gandhi Marg28(4),433-443.

[4] Bhagwati, J.: (2004). In Defence of Globalization.Oxford University Press, New Delhi.

[5] Pieterse, J.N.: (2004) Globalisation and Culture: Global Melange.Rowman and Littlefield Publications Inc., Oxford.

[6] Bhalla, A.S. and Lapeyne, F.:(1999). Poverty and Exclusion in a Global World.Mac Millan Press, Great Britain.

[7] Upadhyay, M.N.:(1976).Handicrafts of India.Swarajya Printing Works, Sucunderabad.

[8] Government of India: Economic Survey 2011-12.

[9] Vijayagopalan, S.: (1993). Economic Status of Handicraft Artisans.NCAER, New Delhi.

[10] Government of India: Annual Report of the Ministry of Textiles 2011-12.

[11] Subrahmanian, K.K.:(2006). An Overview of the Handicrafts Industry.In Subrahmanian,K.K., ed.: The Handicrafts Industry in Kerla: Blending Heritage withEconomics. Dannish Books, Delhi.

[12] Saraf, D.N.:(1991).In the journey of craft development. 1941-1991.Sampark Publication Devision, New Delhi.

[13] Mohapatra, R.C.: (2005).Changing Patterns in the Applique Crafts of Pipili.Orissa Review, 66-67.

[14] Acharya, J. and Lund, R.: (2002). Gendered spaces: Socio-spatial relations of self-employedwomen in Craft production, Orissa, India.NorskGeografiskTidsskrift-Norwegian Journal of Geography 56(3), 207-218.

[15] Jena, P.K.: (2005).Globalization and Indian Handicrafts : Quest for a GandhainWay.GandhiMaarg Vol.30(1), 103-119.

[16] Jena, P.K.: (2007).Orissan Handicrafts in the age of globalization: Challenges and opportunities.Orissa Review, 12-16. 